\title{
OPEN BIM FOR CITIZEN ENGAGEMENT IN SUSTAINABLE RENOVATION PROJECTS
}

\author{
DOI: 10.18485/arh_pt.2020.7.ch30
}

\author{
- Coline Senior \\ Research assistant, Norwegian University of Science and Technology, \\ Høgskoleringen 7A, Trondheim, Norway, coline.senior@ntnu.no
}

\begin{abstract}
The main goal of this paper is to discuss the development of a digital tool based on an open building information model (BIM) for better citizens' engagement in sustainable renovation projects of residential buildings. The ambition is linked with the Sustainable Development Goals (SDGs), supported by the Norwegian government, municipalities and housing cooperatives' Federation NBBLNorske Boligbyggelags Landsforbund (representing of $25 \%$ of residential buildings). The housing sector in Norway represents $67 \%$ of the building stock, which reinforces the importance of addressing sustainability in this sector. The research aims to open the BIM circle to residents, increasing transparency and building trust in decision-making processes, facilitating easier communication, creating a new cultural identity and opportunities for inter-generational relations, visualizing complex technical solutions and ultimately influencing better project outcomes. The methodology used both quantitative and qualitative research methods that were organized through summer-schools and semester courses. In the paper, the analysis of the social/individual barriers to sustainable refurbishment and co-creation of a new interactive tool to achieve citizen engagement, are given. The methods also include the review of the past refurbishment projects, in which we identify successes and failures in the decision-making processes. Those bottom-up approaches are developed to better meet residents' needs by gathering their feedback, leading to improved communication of the benefits of a high standard refurbishment project. A substantial part of gathering information was to listen and not teach to understand people needs and voices ultimately creating a visual survey. Thereby enabling a gamification of the data collection process. The concept for a citizen engagement platform integrating BIM is developed and tested for the purposes of modelling the case site, collecting data and communicating with residents.
\end{abstract}

KEYWORDS _ citizen engagement, co-creation, gamification, SDG, BIM

\section{INTRODUCTION}

The UN Sustainable Development Goals (SDGs) frame ambitious actions for achieving energy and carbon neutrality in the building sector until 2030. ${ }^{1}$ As a signatory of the Paris Agreement, Norway has committed to a $50 \%$ and towards $55 \%$ reduction of greenhouse gas emissions compared to the 1990 level by $2030 .{ }^{2}$ The biggest potential for improving energy efficiency lies within the existing stock of buildings, as $97,5 \%$ of it in Europe does not fall in energy class A. In Norway, housing represents $67 \%$ of the building stock, which reinforces the importance of addressing sustainability in this sector.

The problem posed to the residential building sector, presented by NBBL, the largest housing cooperation in Norway ( $25 \%$ of residential building), is how to communicate the benefits of sustainable refurbishments and gain the support of individual private owners in order to achieve ambitious sus- 
tainability goals.

Preliminary reporting from NBBL and SINTEF $^{3}$ pointed to the following main social barriers and challenges in sustainable renovation of residential buildings with multiple private owners: Coordination of the different stakeholders and their interests; Motivation to take action and participate in the project; Communication of the expanded benefits and added value of sustainable building renovation, such as energy and economic savings in comparison to direct initial costs.

This paper is investigating refurbishment activities in relation to the local urban community (i.e. residents) of Karolinerveien Borettslag in Trondheim, Norway. It is seen as an opportunity to trace SDGs down to local processes in a major segment of the building sector that has a high impact on energy use and efficiency among other environmental impacts.

The initiative is shaped by the opposing triggering factors of residents to buy into needed refurbishments set against wider policy initiatives and sustainability targets to be achieved in the building sector. This research is geared towards the groups which are crucial for achieving the SDGs within the building sector: facility managers, co-operative housing federations and associations (specifically NBBL), the construction industry, citizens and other actors (public institutions, energy providers and academia).

The purpose of this case study is to present the development of an interactive tool for residents' involvement in sustainable building renovation of their residential blocks in the Karolinerveien Housing Cooperative. At this stage in the research, the involvement of users will be generally defined as the participation of residents to the development of a sustainable refurbishment project.

\section{THEORETICAL FRAMEWORK}

\section{Challenges in the building sector and the BIM opportunities}

Cities represent only $3 \%$ of the total surface of the Earth but are responsible for 60 to 80 percent of the total energy consumption and nearly 70 percent of $\mathrm{CO} 2$ emissions. The building sector accounts for $36 \%$ of the global energy use and close to $40 \%$ of $\mathrm{CO} 2$ emissions. The current trends regarding the increasing amount of built square meters indicate that $65 \%$ of the expected building stock by 2060 is already built. This stresses the importance to address the existing stock of buildings in order to mitigate the effects of climate change. It also means that in order to better achieve the overall goal of lowering the sector's impact, it is crucial to set ambitious requirements, going beyond today's regulation. In the residential sector, the individual private owners must take action and invest in the most efficient solutions when engaging into a renovation project. Although two thirds of the global population consider climate change as a "major threat", it is nonetheless a challenge to motivate people to act on it, and barriers remain when addressing their individual property and engaging into sustainable renovation. Social strategies focusing on engaging citizens in formal and informal groups are important to achieve social behavioral changes for climate mitigation and adaptation (Temeljotov-Salaj et al., 2018). Hauge et al. (2013) points social mechanisms that efficiently influence human attitudes and actions, such as: social norms, competition, praise and acknowledgement, social-identity theory, pilot examples, social learning, attention from others, face-to-face stronger together and consensus. In the residential sector, Lindkvist et al. (2014) explains that the adoption of new solutions to improve energy efficiency for example, is usually tied up by the institutional barriers (policy, installation and procurement), financial constraints and social obstacles (resistance to changing the current ways of doing in a society). The $\mathrm{ZenN}^{5}$ research project focusing on the development of nearly zero emission neighborhoods has revealed challenges in engaging

\footnotetext{
1 https://www.undp.org/content/undp/en/home/sustainable-development-goals.html 2 https://lovdata.no/dokument/LTI/lov/2017-06-16-60

3 Stiftelsen for industriell og teknisk forskning, Norwegian Independent research Organization.

4 PEW Research Center. Spring 2018 Global Attitutes Suvey. Q22d

5 ZenN Nearly Zero energy Neighborhoods project
} 
all stakeholders to make well-informed choices and influencing user behavior in their indoor environment. A joint report from NBBL and SINTEF on decision making in housing cooperatives refer to similar challenges, namely in:

_ Coordination: A challenge when working with multiple actors and stakeholders with diverse interests in a residential building, to gather and sort data for decision-making.

_ Motivation: A challenge to motivate residents to engage in traditionally top-down project planning processes such as building refurbishments.

_- Communication: A challenge to communicate the expanded benefits and added value of sustainable building renovation, such as energy and economic savings in comparison to direct initial costs.

The Building Information Model technology as defined by Eastman et al. (2011) is "a modelling technology and associated set of processes to produce, communicate, and analyse building models"6. It has facilitated knowledge-sharing and collaboration between professionals of the building sector. This technology has solved a number of existing issues related to data exchange between different professions by integrating all technical parameters into one common model. The model stores all project information in a standardized manner, making it suitable for interoperability between different software used by every party involved in the project. Although the adoption of BIM is rapidly increasing in the new construction projects, the implementation of BIM for existing buildings' retrofit faces some challenges and is still developing. Gholami et al. (2015) points out the need to provide better and more accessible information to residents in the renovation process as essential. They insist on the potential that lies within the BIM to fulfil that need. Indeed, this technology allows a complete understanding of the project and its consequences on various parameters (energy consumption, GHG emissions, costs, etc.). The authors also found that the accuracy of the information provided via the model and the simulation processes, tend to reassure all stakeholders involved in the project from the design team and the facility/property manager to the homeowners.

As can be seen, improvements in the building sector can have a significant impact on the overall achievement of the sustainability goals as defined by the United Nations. The residential sector however faces a number of challenges, in particular in private owners' involvement and adhesion. The potential for BIM to serve as a facilitator in communicating the benefits of sustainable renovation is still developing and the rest of this paper will be demonstrating the design process of a web-based interactive tool for improved communication in the renovation project of a Norwegian housing cooperative.

\section{CONTEXTUAL ELEMENTS}

NBBL, the largest co-operative Housing Federation of Norway can be seen in our case as the Strategic level of Facility Management. They have decided to take actions towards mitigation of climate change. The tactical level is represented by their local team, TOBB who responsible for the management and maintenance the Karolinerveien Housing Cooperative located in Trondheim, Norway. This urban community consists of seven apartment buildings from 1967 with large outdoor areas. NBBL saw the need of refurbishment as an opportunity to take a step towards a sustainable regeneration of the neighborhood together with an upgrade of the buildings' performances.

The Norwegian University of Science and Technology, NTNU, through their Department of Civil and Environmental Engineering contributed to the development of a research project by organizing summer schools as well as semester courses and guidance of Master thesis related to the theme "citizen engagement in sustainable refurbishment projects". 


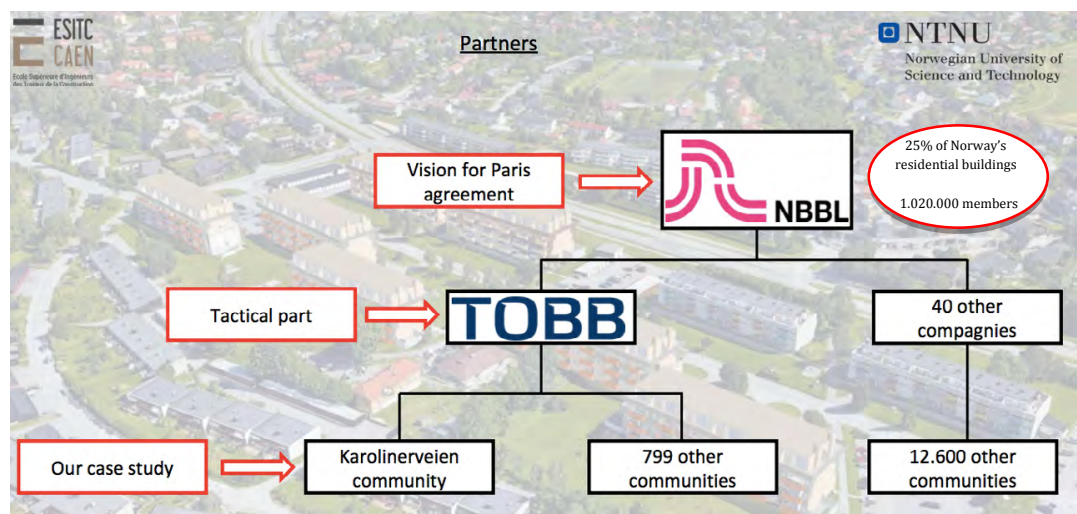

_ Figure 1 Organization of the Facility Management company made by the ESITC students, 2019

\section{AN INTERACTIVE TOOL TO IMPROVE COMMUNICATION}

\section{Primary data collection}

This section describes the initial data collection and design process of the platform and its evolution towards a co-creation approach in which students actively involved residents of the Karolinerveien. During the first Summer School organized at NTNU in collaboration with ESITC, the Caen institute of civil engineering, the students and educators sent 4 weeks developing the concept of an interactive platform to better communicate the benefits of sustainable refurbishment to the private owners of the flats. The goals of the summer school were jointly defined as part of an agreement between NTNU and NBBL. A survey previously conducted by TOBB gave approximately 100 responses (out of 350 apartments total). The results of the survey were used to get a first impression of what needed to be done regarding the refurbishment. The indoor comfort was identified as the main problem. People were experiencing high humidity level, bad ventilation, cold drafts from untight windows and doors resulting also in acoustic disturbance. $62.5 \%$ of the respondents said they had to open the windows in order to get sufficient ventilation in their apartment. This clashed with one of the issues experienced by the respondents, namely the acoustic nuisance from seagulls in the summer. Indoor temperature also revealed itself to be problematic with respectively $779 \%$ and $58,1 \%$ of the participants reporting overall or partial excessive warmth in the summer and excessive cold in the winter. Information were also collected from real estate agencies in charge of the sale of some apartments. They provided information about the area, proximity to facilities and transport, average age in the neighborhood, energy marking but also pictures of inside the apartments and recommendations for energy efficiency improvements at the building level. One observation, being familiar with the Norwegian culture is that people tend to « renovate " their home quite regularly which often results in hiding signs of deterioration for a short period of time until the paint cracks again. This could also explain why people would be more reluctant to take actions towards refurbishment as they don't physically see the problem and therefore the need for it.

This first phase of data collection revealed challenges that lead the team to start thinking about solutions for possible upgrades such as an improved ventilation system, replacing windows, add an extra layer of insulation. These suggestions were brought up through a brainstorming session organized between the students and educators. The session's facilitators encouraged the students to step out of their engineer role and try to think of solutions that could contribute to the well-being of the residents as well. Once the problems and solutions had been identified, the team was left with the challenge of how to communicate them to the residents. 


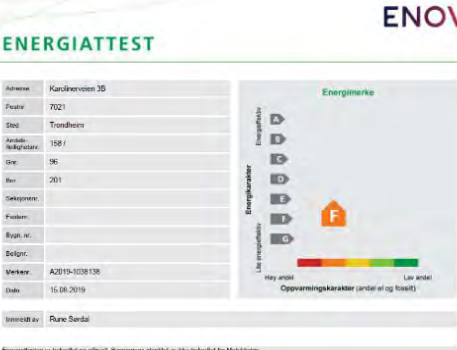

ENOVA

Mulige forbedringer for boligens energistandard

\begin{tabular}{|c|c|}
\hline $\begin{array}{l}\text { Ut fra opplysningene som er oppgitt om boligen, } \\
\text { anbefales falgende energieffektiviserende titak. Dette } \\
\text { er tiltak som kan gi bygningen et bedre energimerke. }\end{array}$ & $\begin{array}{l}\text { Noen av tiltakene kan i tillegg være svært lønnsomme } \\
\text { Tiltakene bør spesielt vurderes ved modemisering av } \\
\text { bygningen eller utskifting av teknisk utstyr. }\end{array}$ \\
\hline \multicolumn{2}{|c|}{ Tiltaksliste (For full beskrivelse av tiltakene, se Tiltaksliste - vedlegg 1) } \\
\hline - Montere tetningslister & - Tetting av luftlekkasjer \\
\hline - Etterisolering av yttervegg & - Utskifting av vindu \\
\hline - Termografering og tetthetsproving & - Temperatur-og tidsstyring av panelovner \\
\hline \multicolumn{2}{|l|}{$\begin{array}{l}\text { - Installere ny rentbrennende vedovn / peisinnsats. } \\
\text { alternativt pelletskamin }\end{array}$} \\
\hline $\begin{array}{l}\text { Det tas forbehold om at tiltakene er foreslattt ut fra de } \\
\text { opplysninger som er gitt om boligen. Fagfolk bor } \\
\text { derfor kontaktes for ả vurdere tiltakene nærmere. }\end{array}$ & $\begin{array}{l}\text { med gieldende lowverk, og det mâ tas hensyn til krav } \\
\text { til godt inneklima og forebygging av fuktskader og } \\
\text { andre byggskader. }\end{array}$ \\
\hline Eventuell gjennomforing av tiltak må skje i samsvar & \\
\hline
\end{tabular}

__ Figure 2 Energy marking and recommendations for improvement issued by ENOVA included in the sale folder of a 2 bedrooms apartment in Karolinerveien 3B. Source: Eiendomsmegler 1

\section{Developing digital content and re-thinking the design process}

The students thought that, due to the average young age in the community, a digital platform with a playful interface could be a good communication medium and they started developing the concept for a website that could host a visualization tool rather than having the tool on its own. That way, the tool would be hosted on a platform that could be accessed from the comfort of the residents' home and would not require any special equipment or skills.

At this stage, the team started building 3D models for visualization purposes and started listing all potential upgrade interventions in a separate document. Following the next step of the traditional design process, the concept of the web-based tool was presented to new researchers in the team. The main outcome of this meeting being that so far, despite trying to develop a tool to interact with people, the team had not been interacting with their intended audience during the development phase. The problem was therefore redefined to make room for feedback collection on both the development of the tool and the issues experienced by the residents in their built environment. While a part of the team continued to develop content for the tool, the others went on field trips to interact with residents directly and start a dialogue with them.

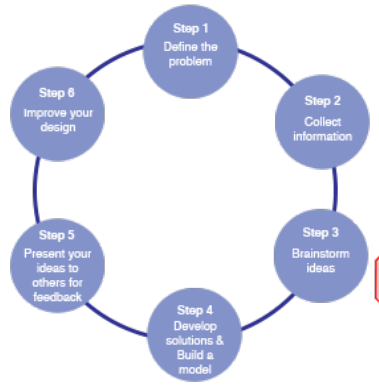

Traditional Design process

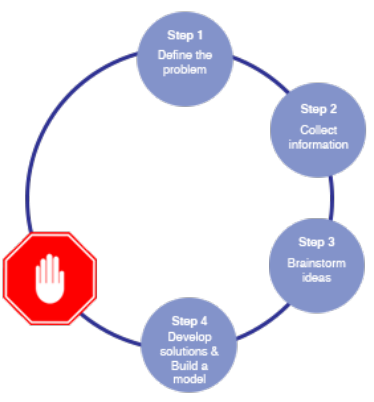

Students initial

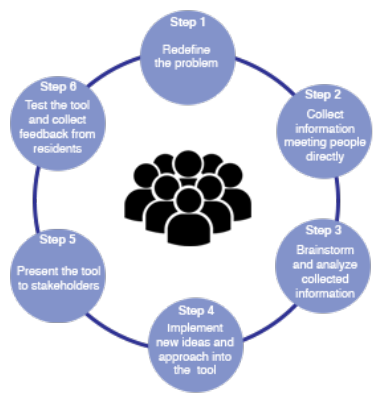

New process using cocreation. Putting people at the centre of the process and actions.

_ Figure 3 Traditional design process and evolution of the team's design process towards co-creation. Source: Adapted from Chicago Architecture Foundation.

Following this, it was decided to divide it into two "mini-games" one collecting feedback and one disseminating information about the potential benefits of sustainable renovation. If the goal is for people to receive tailor-made information, then they should be offered the possibility to give input as well. 


\section{Collecting feedback and communicating on benefits of sustainable refurbishment}

The platform is constantly evolving and can be accessed at www.blimedoss.com. The next section is describing the two main games available on this web-based tool.

The first game was called "pick your picto" and consisted in collecting feedback on previously identified issues in a more visual and playful way, hoping thereby to obtain more responses. The team built 3D models of all five types of apartments identified in the blocks, so people would be able to choose the one they actually live in, and place pictograms representing different issues they might experience at home (noise, humidity, cold drafts, cold temperature, ventilation). The user composes its own "experience picture" and can send the result of that composition and additional comments to the administrators of the site (i.e. the research team) anonymously.
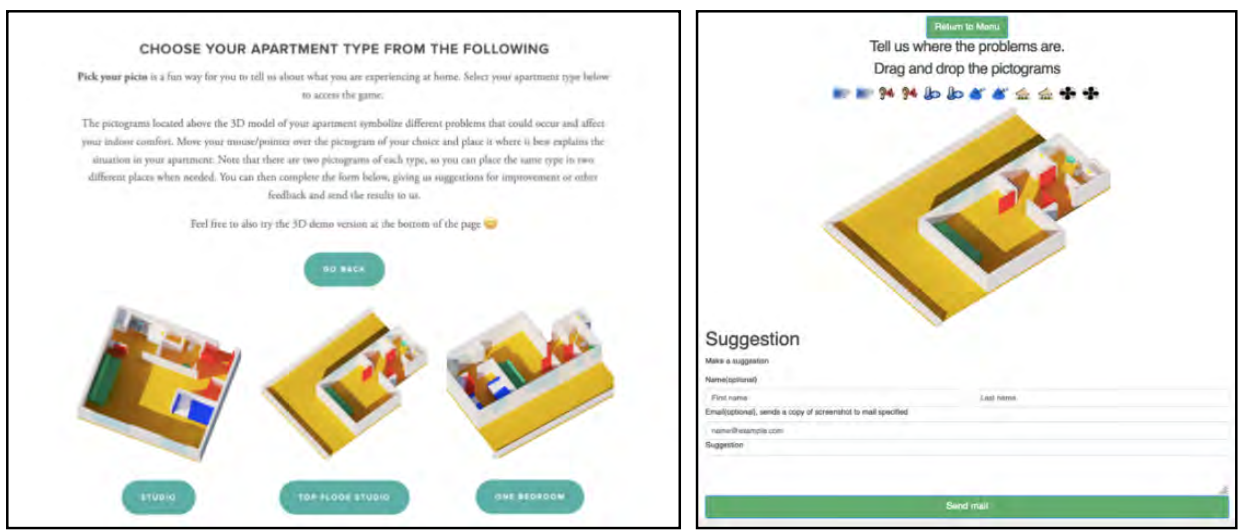

_ Figure 4 Landing page of the "pick your picto" game and interface for the "top floor studio"

Source : https://www.blimedoss.com/feedback

The second game, called "click and tip" was developed to provide tailor-made information on the benefits of sustainable renovation of the block and its surroundings. The user can click on different magnifying glasses placed on strategic elements of the building and its environment (façade, windows, ventilation, playground) to find out how the situation could be improved. There is also a field to send suggestions or questions anonymously.
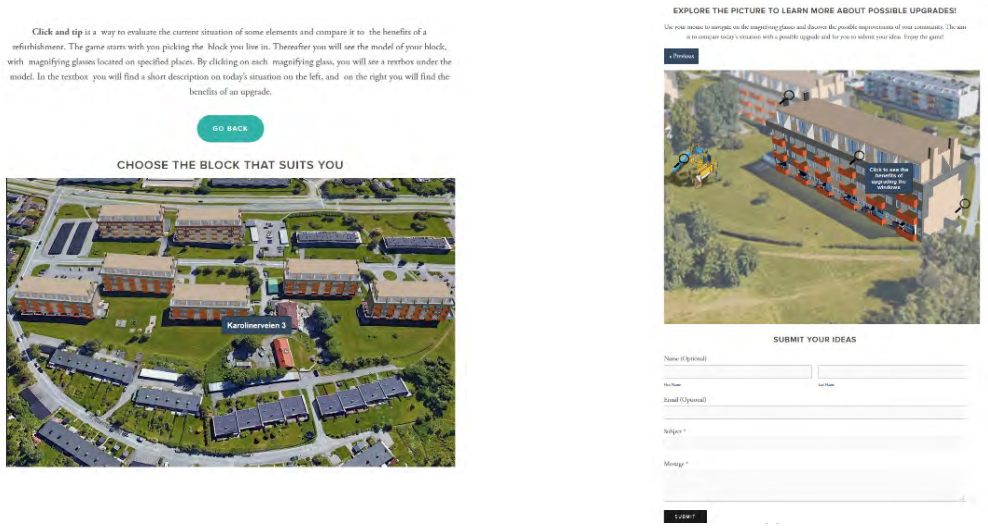

_ Figure 5 Landing page and interface of the Click and Tip game. Source : https://www.blimedoss.com/ benefits 
This game is currently being improved to include more interactivity and a real tailor-made communication at the user level. The ambition is ultimately to create a virtual user interface where residents could see the effects of their decisions in the refurbishment project on their different "levels" such as their environmental impact, well-being, economic, etc. Indeed, work conducted by students through an analysis of "successes and failures" in sustainable renovation of housing cooperatives revealed that communication and transparency in the process were high on the list of users' priorities. Breach of communication and intervention of third parties during the pre-project phase were identified as substantial factors of failures alongside the financial aspect and the lack of options for external funding.

\section{CONCLUSION}

The development of the platform has opened new ways of approaching sustainable building renovation projects in the private residential sector. Putting users at the genesis of the project and providing them with participatory tools that do not require any special skill or physical attendance to workshops. The platform is currently being further developed and a beta version with true 3D models and interaction is available as a test. The goal is to embed the BIM models on the online platform and take advantage of the instant response time enabled by the simulations to give residents an accurate information based on their priorities and experience. Through semester course and master thesis work, the research team is aiming to enrich the tool with more user data and tailor-made information to tackle the identified challenges in coordination, motivation and communication between the housing cooperative organization and its members (i.e. residents). This work is part of a larger collaborative project between NTNU (Academia) and NBBL (Industry), where the main goal is to develop a sustainable accounting strategy for their local branches in order to contribute to the overall sustainability goals. The Norwegian public building sector, through their Directorate of Public Construction and Property (Statsbygg) has been very proactive in implementing BIM in the construction industry. Statsbygg has developed a national strategy and a handbook for the implementation of BIM in all public building projects. However, the private sector and more specifically the residential Facility Management sector is still lagging behind. The fruitful collaboration between Academia and Industry has acted as an enabler of discussions regarding the potential use of BIM beyond expert collaboration, namely in collecting users needs and implementing co-creation processes in sustainable refurbishment projects.

While the primary purpose of the study and the development of the tool was to develop a new way of communicating between end-users and facility managers, it also revealed to have a big potential to implement new features in the BIM technology that could complement highly technical data with some users' input. The ambition for further development is to create a two-way communication between the BIM and the end-users of the space via an interactive web-based platform. The feedback collected and the user-generated renovation scenario would then provide information about which combinations turn out to be the most popular among end users. The concept for a "SIMS"-like interface is currently under development to offer users the possibility to spend their Social, economic and environmental "points" on certain components of the renovation project and see the immediate effects on their personal "levels" (health, finances, $\mathrm{CO} 2$ footprint, real estate value).

\section{REFERENCES}

- C. Eastman, C. M. Eastman, P. Teicholz, and R. Sacks. 2011. "BIM handbook: A guide to building information modelling for owners, managers, designers, engineers and contractors": Chapter 1, p. 16 John Wiley \& Sons.

_ Gholami, Elaheh, Kiviniemi, Arto, Kocaturk, Tuba and Sharples, Steve. 2015. "Exploiting BIM in energy 
efficient domestic retrofit: evaluation of benefits and barriers". In: 2nd International Conference on Civil and Building Engineering Informatics ICCBEI, 2015-04-22 - 2015-04-24, Tokyo.

_ Klima- og Miljødepartementet. 2017. "Climate Law". Norwegian State Law. Accessed December 13, 2019. https://lovdata.no/dokument/LTI/lov/2017-06-16-60

_ Lindkvist Carmel, Karlsson Anja, Sørnes Kari, Wyckmans Annemie, "Barriers and Challenges in nZEB Projects in Sweden and Norway", Energy Procedia, Volume 58, 2014, p. 199-206.

_ Norges Boligbyggelags Landsforening og SINTEF Byggforsk,.2011. "Få oppslutning om oppgradering! Veileder for styrer i borettslag/sameier" https://www.nbbl.no/Portals/1/NBBLs\%20filarkiv/PDF\%27er/ Rapporter/Fagrapporter/2015-11-13\%200ppslutning\%20om\%20oppgradering.pdf

_ PEW Research Center. Spring 2018 "Global Attitutes Suvey". Q22d

_ UN Environment and International Energy Agency. 2017." Towards a zero-emission, efficient, and resilient buildings and construction sector". Global Status Report.

_ UN Development Programme. 2015. "Goal 11 : Sustainable cities and communities" Accessed February 28, 2020. https://www.undp.org/content/undp/en/home/sustainable-development-goals/goal-11-sustainable-cities-and-communities.html

_ Buildings Performance Institute Europe. 2017. "97\% of buildings in the EU need to be upgraded" Accessed December 12, 2019. http://bpie.eu/publication/97-of-buildings-in-the-eu-need-to-be-upgraded/

_ Temeljotov Salaj, Alenka; Hjelmbrekke, Hallgrim; Bjørberg, Svein; Hauge, Åshild Lappegard; Lohne, Jardar. 2018. "Value sharing model for urban development." Conference of Interdisciplinary Research of Real Estate, Groningen, September 20-21, 2018. Book of proceedings p. 11-19.

_ UN Development Programme. 2015. "UN Sustainable Development Goals", Accessed December 12, 2019. https://www.undp.org/content/undp/en/home/sustainable-development-goals.html 